\title{
“Outposts of Britain" The General Post Office and the Birth of a Corporate Iconic Brand, 1930-1939
}

\section{Introduction}

In his monograph, How brands become icons. The principles of cultural branding (2004) Holt argues that in modern consumer societies some brands become iconic. They symbolise and materialise certain aspects of a shared culture. These brands are valued by consumers because they are able to incorporate aspects of them into their own identities. Brands can symbolise a range of meanings such as gender, autonomy, success, rebelliousness, environmentalism or lifestyle (Holt, 2002, 2004). They become iconic by narrating myths that combine both historical fact with ideology that appeal to individuals and groups. The stories provide social value by their capacity to resolve contradictions between national ideologies and individual experience (Holt, 2004, pp. 1-12). Individuals may aspire to lead authentic, meaningful lives but find themselves unable to do so. In these situations the myths that iconic brands tell are able to resolve anxieties generated by such tensions. In the 1960s, for example, the Volkswagen Beetle in the United States assuaged fears generated by the rise of a corporate, materialistic and conformist society by creating a brand that was based on a myth of bohemia, idiosyncrasy and authenticity (Holt, 2004, pp. 65-72). Similarly in the 1990s Budweiser was able to ease anxieties of emasculation amongst American men by drawing on stories of male camaraderie, hanging out, beer and sport (Holt, 2004, pp. 112120). The Beetle thus came to symbolise autonomy in a society that was felt to be conformist, while the Budweiser evoked masculinity in an environment that was seen by many men as undermining and eviscerating their sense of manhood.

As these two examples demonstrate, myths play a peremptory role in the construction of iconic brands. Holt applies an anthropological approach to myths. All societies are created and integrated by common cultures, and myths reinforce these by recanting stories which demonstrate and reinforce their shared values, beliefs and practices (Levi-Strauss, 1995). Myths thus play a role in the socialisation of individuals, encapsulating social truths that play a part in the construction of personal identity In addition to this anthropological approach, Holt applied the work of the French philosopher Roland Barthes and the American cultural historian Richard Slotkin. Developing the semiotics of the Swiss linguist Ferdinand de Saussure, Barthes argued that myths were ubiquitous in the modern world in phenomenon such as political parties, family structures, sport, media, the arts, consumption and brands (Bathes, 2000). All of these relied on mythical, symbolic narratives for their reproduction and legitimacy. In addition, Barthes argued that these myths were fundamental to the structuring of meaning in modern society. From Slotkin, the relationship between myths and the development of national identity was elaborated. Slotkin demonstrated this through his historical analysis of the role of the American frontier in the construction of American national identity (Slotkin, 1985, 1998; Holt, 2006, pp. 361-363). The frontier became an ideological site where it was claimed that through a process of conquest and confrontation American identity was created. This began the American frontier myth which was promulgated by novels and film. The conquest of the frontier took on a mythical role which came to symbolise American values and ideals. It was constructed in the popular imagination 
as a milieu where men could test and exhibit their masculinity. This became particularly important in the twentieth century, when the frontier had been closed off, yet its need in a modern, urbanised environment had become more acute.

Holt introduced the concept of 'populist worlds' to explain why certain brand myths become accepted. Populist worlds are defined as, 'potent cultural sites' that have not been contaminated by corporate or political activity, where behaviour is intrinsic and voluntary rather than instrumental and forced. They reside in liminal spaces such as youth culture, sport, popular music, minority socio-ethnic groups and marginalised communities, and are valued for their authenticity and autonomy (Holt, 2004, pp. 58-59). Brand myths obtain their potency by originating in these sites, which embellish them with credibility and meaning. For the Volkswagen Beetle this was the bohemian world of the 1960s, whilst for Budweiser it was the Afro-American urban environment of America in the 1990s (Holt, 2004, 65-72, pp. 112-120). Finally, a central aspect of Holt's approach to iconic brands is his use of genealogy. Genealogy is a form of historical analysis that combines the ideological with the historical in the form of discourses that script and structure social behaviour during certain periods. The myths that brands generate are cultural discourses that generate their power from the wider socio-cultural milieu and their ability to intertexualise with cultural scripts such as films, TV shows and music, and iconic figures such as sports personalities and film stars (Holt, 2006, pp. 356-359). The key point for Holt is that episodically there are cultural shifts that change the beliefs and practices of a given society and render existing myths obsolete. To survive, iconic brands must construct new myths and narratives that conform to the new order (Holt, 2004, 39-56).

Whilst the cultural approach to branding has grown (McCracken, 2005; Schroeder \& SalzerMorling, 2006), the application of Holt's work has been muted. With the exception of Smith and Speed's application of cultural branding to the modern British Conservative Party (2011), there has been no application of Holt's work and his model of iconic branding has been ignored. This article is thus one of the first to apply Holt's theory on iconic branding, and will do so in relation to the General Post Office (GPO) in Britain in the 1930s. It has two goals; to historically understand the dynamics of iconic branding at the GPO and to examine the process of iconic branding in relation to corporate brands. By doing so it hopes to elaborate on Holt's work on iconic branding and develop a new theory for the process of corporate branding. In order to do this it will apply three concepts; corporate identity, corporate branding and corporate communication. For the sake of clarity for the ensuing discussion, these three concepts will be briefly discussed and defined.

Corporate identity relates to those elements in an organisation which differentiate it from other organisations (Van Riel \& Balmer, 1997; Balmer \& Soenen, 1999; Balmer, 2001; Balmer \& Greyser, 2007; Abratt \& Kleyn, 2012). On the one hand it relates to the ethos and values of an organisation and its members, which is strongly related to its organisational history and culture. On the other it relates to the organisation's strategy, sense of purpose, business activities and relationship with stakeholders. Van Riel and Balmer (1997) have claimed that corporate identity is manifested through behaviour, communication and symbolism. A positive organisational identity can result in a range of benefits for the 
organisation that includes positive relationships with stakeholders, improved market position, superior financial performance, the ability to attract strong employee candidates and enhanced reputation. Balmer and Soenen (1999; Balmer, 2001, pp. 259-261) have argued that the corporate identity consists of the soul, that is an organisation's subjective elements including its organisational culture, the mind which relates to its ethos, strategy and product performance, and the voice which encompasses its internal and external communication. The management mix of corporate identity consists of environmental forces, stakeholders and reputations. The corporate brand is closely related to corporate identity and encompasses the reputation and credibility of the organisation, its ability to differentiate itself from peers and competitors, and its relationship with its stakeholders (Balmer, 2001; Hatch \& Schultz, 2008; Melawar, Gotsi \& Andriopoulos, 2012; Abratt \& Kleyn, 2012; Balmer, 2012). All three relate to what Balmer terms the corporate brand proposition (Balmer, 2001, p. 281). This is closely related to corporate communication that encompasses all the communication channels and tools that the organisation uses in relation to internal and external stakeholders, and is used to articulate and enhance corporate identity and the corporate brand (Balmer, 2001, p. 253).

This article will begin with an outline of its methodology of historical analysis. It will then provide a historical overview of the GPO in the interwar period. Following this, based on Holt's model of iconic brands, it will outline the social and cultural anxieties that Britain faced in the interwar period, and will discuss the myths that the GPO produced that countered these fears and helped create an iconic brand. Based on the findings, the article will provide an adapted version of Holt's model of iconic branding that incorporates corporate brands. Since the article follows an empirical and inductive approach it is felt that it is appropriate that its adapted theoretical model should follow the research. Balmer has noted that case studies are an appropriate research methodology in relation to corporate identity due to the lack of empirical research on the subject (2001, p. 268). They can be used to build theory rather than to test it. This is precisely what this article to purports to achieve; the development of a theory on iconic corporate branding based on historical, empirical analysis. As a result it is felt that the model should follow the historical case study of the GPO rather than precede it.

\section{Methodology}

This article will use historical methodology through the development of a historical case study. The historical method is concerned with the process of change and with analysing past environments (Carr, 1961; Smith \& Lux, 1993). Historical methodology resembles other disciplines in the social sciences (Smith \& Lux, 1993, p. 599). It requires research design, encompasses primary and secondary data and is concerned with issues of reliability and validity. It also applies theory, often taken from other disciplines. Unique to the historical method, however, is its reliance on original historical data. Historians analyse historical data to reconstruct the past so as to analyse and understand it. Good historical research will analyse a broad range of historical data from archives, which it will cross-reference (Smith \& Lux, 1993, p. 601). It will critically analyse this data, often referred to as 'source criticism', and will rigorously cite this data in footnotes in order to demonstrate the validity of its sources. It will also adhere to the principle of 'historical representation', the idea that historical accounts and interpretations pertain as closely as possible to past events 
(Ankersmit, 2001). Finally historical analysis must be original. It cannot simply retell what has already been accounted for. Creating historical reconstructions based on existing histories does not amount to historical research.

Historical methodology has been widely applied to the study of marketing over the last thirty years. In addition to Holt's work, articles that have applied history to marketing have regularly appeared in marketing and business journals (Smith \& Lux, 1993; Schwarzkopf, 2009; Karababa \& Ger, 2011). Furthermore, important research has been done on the history of marketing within the field of business and cultural history (Tadajewski \& Brian Jones, 2014). One must, however, make a distinction between papers that are purely historical in nature, that is are only concerned with an event in marketing that happened in the past, and those that use the historical method in order to elucidate an aspect of marketing in the present. Articles that have appeared in historical journals relate to the former, whilst Holt's work and those that appear in journals such as The Journal of Consumer Research mainly encompass the latter (Zhao \& Belk, 2008; Humphreys; 2010, Smith \& Speed, 2011; Karababa \& Ger, 2011). It is useful here to follow Ruth Ann Smith and David S. Lux's dictum that the principle role of the historical method for present day consumer research is to achieve one of three interpretive aims; to develop a theory of change, to test or corroborate an existing theory or to explain anomalies unaccounted for under current theory (Smith \& Lux, 1993, pp. 599-601). This paper falls into the second type of historical marketing research and hopes to achieve the second and third aims of Smith and Lux's typology.

\section{The GPO in the interwar period, 1919-39}

In the interwar period the GPO, was the largest organisation in Britain, employing over 280,000 workers in the 1930s (Campbell-Smith, 2011, p. 304). The organisation was in fact several businesses. Its primary activities revolved around communication, principally postal services, telegraphs and the telephone. In addition, the GPO operated the Post Office Savings Bank, and oversaw the broadcasting license for the British Broadcasting Corporation, which it represented in Parliament. Finally it was responsible for the payment and supply of many government benefits, including old age pensions and national insurance stamps. With an increase in social welfare from the liberal reforms of 1906-14 onwards, the GPO for many people in Britain became the embodiment and symbol of the state. It was the one government institution that most people regularly interacted with (Campbell-Smith, 2011).

In the 1920s and early 1930s the GPO came under intense criticism for failing to expand Britain's telephone network. The number of Britons on the telephone lagged far behind the United States, Germany and Scandinavia. Its critics argued that much of this was due to a failure to market the telephone. The post office refused to advertise and trailed behind other organisations in Britain in terms of publicity. In response to this criticism the GPO established a telephone publicity committee in 1931. ${ }^{[1]}$ Many of the people on the committee came from the Empire Marketing Board (EMB), another governmental organisation whose role was to promote trade within the British empire. ${ }^{[2]}$ With the adoption of tariffs by Britain in 1931 the organisation was wound down and many of its staff were transferred to the GPO. Work in film, advertising and exhibitions, which the GPO instigated in the 1930s, was a 
continuation of the innovative work carried out at the EMB in the 1920s. Other departments in the GPO such as the saving bank, mail and telegrams joined the publicity committee in July, 1933. ${ }^{[3]}$ This acted as the basis for the founding of the public relations department at the GPO in that year, the first of its kind established in Britain.

The department became responsible for some of the most innovative work in PR and marketing communications in the 1930s in Britain. The head of the department, Sir Stephen Tallents, went on to establish the PR department at the British Broadcasting Corporation (BBC) in 1935 and played a leading role in the foundation of the British Chartered Institute of Public Relations in 1948 (Anthony, 2012). The PR department at the GPO used public relations to create a feeling 'telephone mindedness' in Britain, which it then integrated with other promotional techniques such as advertising, sales promotions and direct marketing. The work carried out at the GPO in the 1930s laid a major foundation for the emergence of public relations in Great Britain. It was at the GPO that a clear distinction was made between selling advertising and prestige advertising; the former related to promoting services while the latter referred to corporate communication and corporate branding. ${ }^{[4]}$ The GPO carried out market research, identified target markets, interacted with stakeholders, planned communication campaigns and developed an innovative system of corporate communications for a range of products and services. ${ }^{[5]}$

\section{Findings}

\section{Anxieties}

For an iconic brand to be effective it must resolve tensions and contradictions within a sociocultural context. Interwar Britain was inundated with such anxieties. These were fears that were harboured by many of its members and institutions, and whose stigmata still remain in popular memory and culture today. For the purposes of this article two areas of social stress will be examined. The first was the socio-economic upheavals of the interwar period, partly engendered by the First World War, 1914-1918, and the class conflicts that this created. The second was the fear of Britain's decline as a global power and the loss of Empire.

Britain had suffered heavy losses in the First World War. It lost 750,000 men, one-tenth of the population. Hundreds of thousands returned with debilitating wounds and illnesses. Spanish Avian Flu, which broke out in the UK in July, 1918 claimed a further 230,000 deaths within 18 months (Pugh, 2009, pp. 4-6). The war also had an egregious impact on the economy. The nation was heavily in debt, and had lost key international markets to the US, Japan and India (Pugh, 2009, pp. 77-78). Economic and social capital such as housing and transport was depleted and undercapitalised. Inflation shook the economy and continued to do so throughout the immediate post-war years. Finally, the war disrupted global trade and investment for much of the interwar period. Arguments over wartime debt, reparations and growing political and economic nationalism led to the erection of trade tariffs and the halting of overseas investment (Kennedy, 1989, pp. 362-366). For a country as dependent on international trade as Britain the effects were draconian. The economy was in recession for most of the 1920s and early 1930s. 
These shocks impacted on every sector of society. The aristocracy had lost many of their offspring due to the high death rates of the officer class in the conflict, and were hit by death duties (Pugh, 2009, pp. 4-5, p. 349). The middle classes saw their savings reduced by inflation and their static incomes unable to keep pace with rising prices (McKibbin, 2000, pp. 50-53). The politician and journalist Charles F.G. Masterman commented in 1922, "It is interesting and a little pathetic to trace the influence of the war and a rise in prices to the slow disintegration and decay of the whole standard of civilisation of Middle-Class England" (1922, p. 58). He noted that this class felt, "more bitterly deserted in this unseen combat of economic standards than any other class of the community” (Masterman, 1922, p. 68). Yet it was the working classes who bore the heaviest cost in the form of unemployment. The number of people out of work rose to over two million in the early 1920s, subsided to 1.1 million by 1929 and then increased to over three million by 1933 due to the global slump following the Wall Street Crash of 1929. Whilst unemployment decreased thereafter, it never fell below 10 per cent (Pugh, 2009, pp. 77-81; McKibbin, 2000, pp. 111-114). For a country that had experienced relatively light employment during the Victorian and Edwardian periods, the experience was unprecedented. What exacerbated this was its concentration amongst the working classes in the industrialised areas of the North. A stream of novels such as Orwell's The Road to Wigan Pier, Greenwood's Love on the Dole and Wilkinson's The Town that was Murdered all bore witness to the sufferings of this class (Pugh, 2009, p. 77).

This invariably led to social tensions during the interwar period (McKibbin, 2000, pp. 5459). The early 1920s witnessed strikes by organised labour, which culminated in the General Strike of 1926. The rise of an organised, militant working class was particularly threatening to the middle classes. Masterman noted the antipathy of the bourgeois residents of his fictitious suburb of Richford towards the working class. 'Richford', he observed, 'hates and despises them, partly because it has contempt of them and partly because it has fear of them' (Masterman, 1922, p. 54). This was a fear, he noted, accentuated by an increase in combination amongst the working classes,

It [the middle class] gazes at the programmes of the miners' unions and railway workers with something of the emotions with which primitive peoples, divining an eclipse, watch the shadow slowly creeping over the sun. These emotions are compounded of fear and wonder, with a sense of helplessness in the face of a calamity difficult to endure. (Masterman, 1922, p. 76.)

Whilst direct industrial action subsided after 1926, a disgruntled trade union movement meant that its threat never disappeared and industrial relations were marred by absenteeism and an emergent shop steward movement (McKibbin, 2000, pp. 137-151). The period also witnessed the Hunger Marches of the 1930s, when hundreds and sometimes thousands of unemployed men marched to London demanding work (Pugh, 2009, pp. 81-86).

The second area of tension to which the GPO brand responded was a perceived decline in both Britain's global standing and the British Empire. America's economy went from strength to strength in the 1920s, when it emerged as the uncontested major economic power in the world (Kennedy, 1989, pp. 423-430). America's dynamic corporations, its vibrant 
culture typified by Hollywood and jazz music, and the Washington Naval Agreement of 1922, which recognised parity between the United States and Great Britain in terms of naval strength, all symbolised this (LeMahieu, 1988, pp. 91-98). Japan too grew in economic and military strength in the interwar period and invaded Manchuria in 1931 and China in 1937 (Kennedy, 1989, pp. 385-392). Fascist Italy and Nazi Germany also appeared as resurgent powers. This can be contrasted with a sense of decline in British power, exacerbated by the depressions of the 1920s and 1930s, social tensions, military insecurity and a hostile international environment. In 1933, for example, a number of articles appeared in the popular press reporting Britain's military weakness and inability to face a future major conflict. The Daily Mail in October, 1933, reported that Britain's air force was 5,000 planes below strength and would be outnumbered two to one if attacked by a major power (1933b). The Daily Express reported on the anniversary of the Battle of Trafalgar on the parlous state of the Royal Navy. Since 1932 personnel had been reduced by 44,367, while the United States had increased its numbers by 40,000 and Japan by 38,000 (1933). A cartoon accompanying the article showed a decrepit, flea-bitten and begging lion entitled, 'The British Navy', playing an organ grinder with a model of the flag-ship 'Victory', under Admiralty Arch. Two signs were next to him. The first read, 'I am the sole support of the trade routes,' the other, 'Kind friends I am reduced in circumstances through no fault of my own!' Admiral Nelson's statue looked disapprovingly on at the scene (Figure 1).

This perception of decline was augmented by a weakening of the British Empire. A paradox of the interwar period was that just as the British Empire reached its apogee in size by its acquisition of German colonies and Ottoman territories it began to decline. In 1922 Britain recognised the independence of both Southern Ireland and the Kingdom of Egypt. The Balfour Declaration of 1926 and the Westminster Statute of 1931 recognised the independence of Britain's dominions (Canada, Australia, New Zealand, Newfoundland, South Africa and Ireland) in both domestic and foreign affairs (Kennedy, 1989, pp. 369-371; Pugh, 2009, pp. 406-412). In the 1930s, South Africa became increasingly isolated from Britain and refused to cooperate in Empire defence. Most egregious to imperialists, however, was the increasing autonomy of India, which combined both British governmental acquiescence, and opposition to British rule by Mahatma Gandhi and his supporters. The Government of India Act of 1935 augmented the power of the Indian Government and its regional assemblies, and effectively gave India dominion status in all but name (Pugh, 2009, p. 412). Whilst it is arguable to what extent the public supported the Empire, what is beyond doubt is that in the interwar period Britain remained an imperial power. The Empire was intricately interwoven into Britain's position in the world. Any decline in Empire was equated with a decline in power and global prestige. 
Fig 1. Anxieties of Military Decline. (c) The British Library Board. Courtesy of The British Library

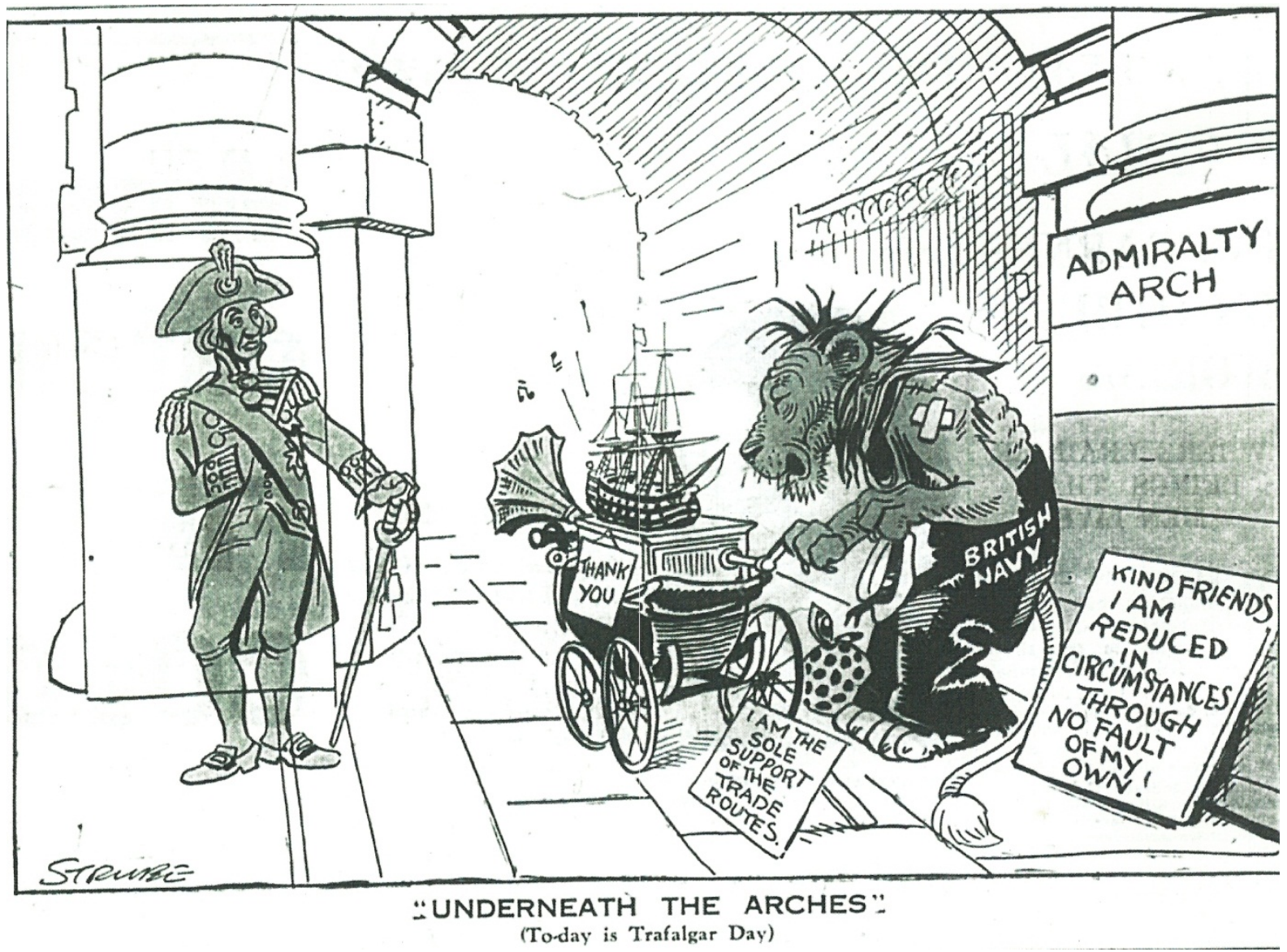

Source: Daily Express (1933), “If Trafalgar is Fought Again”, 21 October, p. 10.

\section{Resolutions: myths of national cohesion, imperial unity and technology}

In the 1930s the GPO, equipped with its public relations department, created myths of national identity, imperial unity and technology. In so doing it countered tensions and anxieties in British society and constructed a powerful iconic brand. In relation to the first, the GPO created a myth of nationhood, which was based on qualities of community, shared traditions, real people, everydayness, co-operation and diversity (Anthony, 2011). The GPO was not original here. In the interwar period British national identity reconfigured itself. Earlier, more grandiose and institutional symbols of liberty, monarchy, parliament, navy, empire and race were downplayed. National identity increasingly focused on shared national characteristics - what increasingly became called the British national character. It centred on Britain itself and the British countryside, divorced from the diversions of the outside world. Furthermore, it was an identity that focused on normal British people and their everyday lives, on the farm worker, the coal miner and the office clerk, and also on the rich panoply and diversity of Britain, on its regions, its trade and industries and its manifold traditions (Mandler, 2006, chapter 5). 
In so doing the GPO had two powerful advocates. The first was the founder of its PR department, Sir Stephen Tallents (Anthony, 2012). In 1933 Tallents published a pioneering pamphlet entitled, The Projection of England (1933). In it he called for the establishment of a body that would promote Britain abroad in an effort to promote the country's interests. Of particular interest were the building blocks from which Tallents proposed to construct this national projection. Whilst acknowledging the importance of Britain's monarchy and navy, he also pointed to Britain's literature and characteristics of fair play, disinterestedness, justice and law and order. In addition, Tallents argued that national sporting and ceremonial events such as the Derby, the Oxford-Cambridge Boat Race and the Trooping of the Colours should be included, alongside more prosaic symbols such as London buses, the London underground railway, football and gardening. Similarly, in 1935 Tallents emphasised in a paper on GPO publicity the need for the construction of a unifying national identity, "We need to build up, piece by piece, a picture of our own people, and also for others, of what this country has done, is doing and seeks to do in its endeavours to equip itself ... to meet a wholly new range of modern conditions." ${ }^{[6]}$ In attempting to paint this picture, Tallents was aided at the GPO by John Gierson, the head of the GPO Film Unit and pioneer of the documentary film in Britain (Aitken, 1990). Grierson came to the GPO with a powerful ideology of the need for film to integrate citizens into the life of nation and state. Film held the possibility of educating and informing ordinary people, and of holding up to them their own lives as a source of drama and inspiration, rather than what he saw as the diversions of Hollywood (LeMahieu, 1988, p. 169).

In the 1930s, the GPO projected the British nation to its peoples. In each of these depictions it spun the consistent message that through the communication services it supplied to the British people, through its letters, its telegrams, and its telephone calls, it created the weave and weft that created a United Kingdom. The GPO celebrated both the diversity and the connections of the British peoples and Britain's regions. In its series of posters, 'Outposts of Britain’ designed by Edward McKnight Kauffer in 1937, for example, the GPO depicted the different parts of Britain that it delivered mail to. Modernistic photographic posters (an innovation of the period) framed in artistic lithography emphasising imagery and colour, depicted postmen delivering the post in Northern Ireland, the Pool of London, in Northern Scotland and at Land's End. ${ }^{[7]}$ The series depicted both the variety of Britain at its most remote corners, and the heroic services that the ordinary postman performed in uniting them. Here was a montage not only of the geography of the United Kingdom, but also of the adhesive services that the GPO provided. 
Figure 2. GPO Outposts of Britain Poster, 1937. (C) Royal Mail Group Ltd 2011. Courtesy of The British Postal Museum and Archive

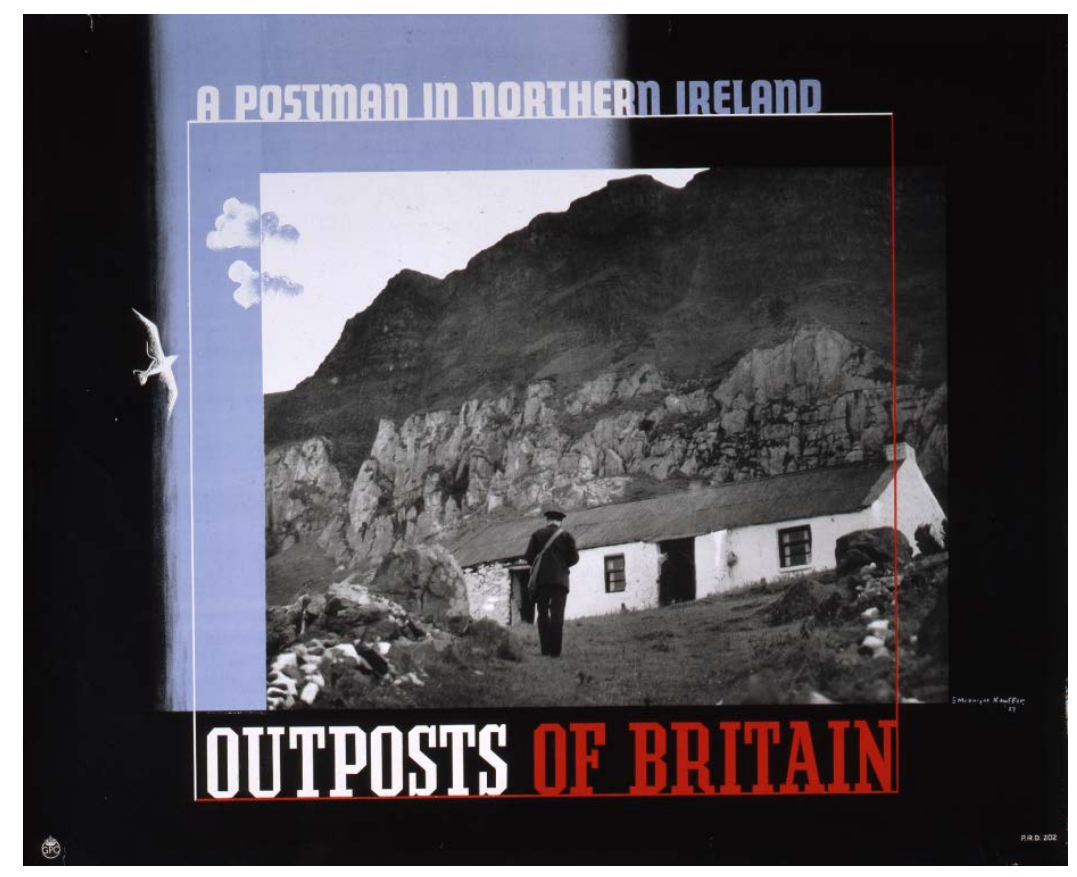

Source: Royal Mail Archives, POST 110/3183, 'Outposts of Britain A Postman in Northern Ireland'.

Equally striking were the documentary films that the GPO made and distributed through its GPO Film Unit. This was a highly innovative and creative body that made a large number of films in the 1930s and promoted the GPO and its services. These were predominantly short films of between five and twenty minutes long, and were made up of documentaries, entertaining short dramas and cartoons (Aitken, 1990). In the 1930s other British organisations such as Shell-Mex, Imperial Airways and the British Commercial Gas Associations would establish similar film units (Heller, 2010; LeMahieu, 1988, p. 169). The films of the GPO were distributed in a number of ways and had wide exposure. They were shown in commercial cinemas, usually as shorts before the main film, they were rented out by the Film Unit itself to schools and private civil associations such as film societies and social and community clubs; and they were shown by the GPO at its theatre in Soho, London, and at its various Post Office shops and exhibitions, which it ran across the country (Suga, 2011, pp. 19-20). ${ }^{[8]}$ By 1935 the GPO had even established a mobile film unit that visited schools and other civil associations across Britain. ${ }^{[9]}$

One film that depicted British life and projected the nation is Calendar of the year. Made in 1936, it fulfilled Tallent's desire for a theatrical portrayal of the nation. Calendar of the year guided the viewer through the four seasons and showed how, in each, the GPO was central to Britain. It celebrated the nation and the British way of life (Spice, 1936). In the winter the GPO kept ships safe at sea from storms, in the spring it helped farmers to market their products. The spring flower crops and Jersey potatoes were shown being harvested and distributed. Summer was announced by people swimming and enjoying themselves in an 
outdoor lido. The scene then shifted to London and showed the Trooping of the Colour, the London fashion season and the Russian Ballet at Convent Garden Opera House. Next the summer sporting events were shown; yacht races, dirt track motor racing, cricket and, most importantly, the Derby. All depended on the GPO for their results to be broadcasted. Following this the focus moved to people going to the seaside for their holidays. The Post Office was vital for the sending of postcards back home to loved ones: 180,000 are sent, we are told, from Blackpool every day of the August bank holiday. In the autumn people were shown returning to work. Scenes portrayed lambs being sold in a market at Lanark in Scotland, docks receiving ships from all over the world, Lloyds of London, the London Stock Exchange and the Bank of England busily transacting the finances of the country. Finally, winter arrived, people flocked to football matches and Christmas approached. People were shown shopping in Oxford Street, London, fathers grumbled that they were not millionaires, children became mesmerised by toys, and the GPO continued working throughout the holiday to make all this possible.

Figure 3. Christmas Arrives in Calendar of the Year, 1936. (c) The British Film Institute. Courtesy of The British Film Institute

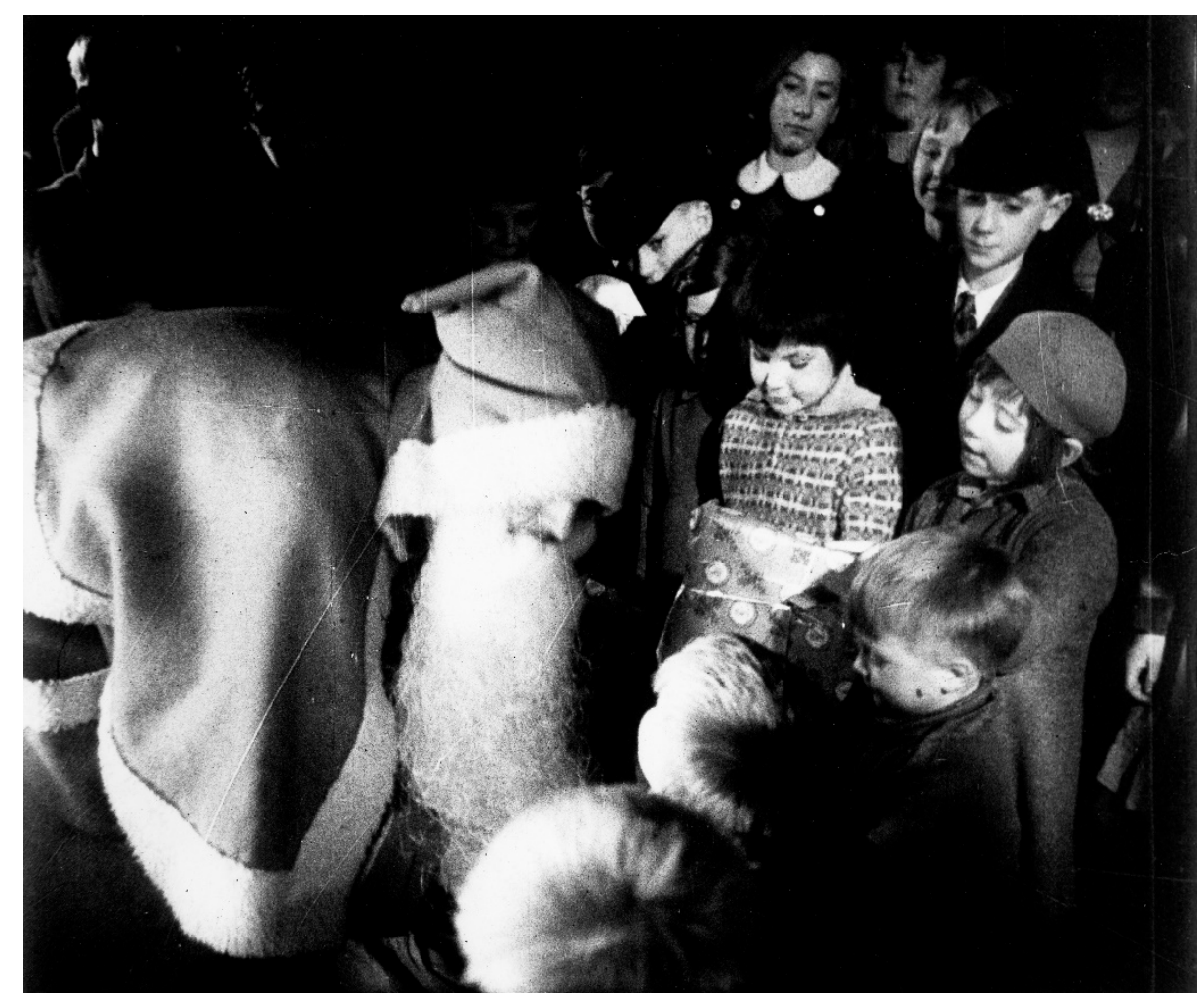

Source: British Film Institute, BFI-00n-ziw

\section{Imperial unity and technology}

In the 1930s the GPO had created one of the most sophisticated and comprehensive systems of global communications in the world. With a large but scattered empire, Britain's 
development of international telecommunications was not surprising. The GPO achieved this through its development of airmail and international radio telephony. By the end of the 1930s a letter could be sent by air to virtually any part of the British Empire for 11/2 pence, and Britain's telephone network was connected with nearly every telephone on the planet (Campbell-Smith, 2011, pp. 319-322). Its international telephone exchange in London was known as the 'Switchboard of the World' due to its role in connecting many of the word's telephone systems. In addition, its research station at Dollis Hill, London carried out ground breaking research. These achievements were actively communicated to the British public and interwoven into the GPO brand. In so doing, they created myths of imperial unity and strength through technology.

In addition to posters, advertisements and films, the GPO communicated its narratives of imperial unity and technology via newspaper articles and newsreels which were shown to cinema audiences. ${ }^{[10]}$ Press releases were sent to Britain's newspapers, to magazines and periodicals, and to newsreel companies such as Gaumont and Pathé news. ${ }^{[11]}$ Some of these newsreels were three or four minutes long and were, in effect, mini documentaries. The GPO assisted Pathé in providing them with film footage from the productions of the GPO Film Unit. Such use of third party endorsement and public relations was highly effective for its corporate brand. The GPO was able to reach millions, far more than its posters, advertisements and films. The messages sent appeared more credible as they came from 'independent' and apparently authentic sources. In addition, the GPO used a sophisticated form of integrated marketing communications, often putting advertisements for services such as airmail and the telephone several pages after the editorial in newspapers. ${ }^{[12]}$

A central component of the GPO's myth in relation to airmail and global telephony was the strengthening of Empire that this provided via communication and advanced technology. In relation to the first, it staged events to celebrate achievements, such as the first dispatch of airmail to various destinations within the British Empire. These were attended by speeches from the postmaster general and other dignitaries, and involved ceremonies such as the franking of mail by the postmaster general. Such theatrical displays were highly newsworthy and were attended by journalists and camera men, whom the GPO provided with press editorials and speeches often written in full. On December $10^{\text {th }}, 1934$, for example, the first airmail service to Australia took off from Croydon, London on the airship Hengist. The event was marked by speeches from the postmaster general, Sir Kingsley Wood, the air minister, Lord Londonderry, and the chairman of Imperial Airways, Sir Eric Geddes. Special mail entrusted to Lord Londonderry, including letters from the King, the Queen and the Prince of Wales to the Duke of Gloucester at Auckland, New Zealand, was handed to the postmaster general. He franked the letters with a special cancelling stamp, sealed them in a blue silk bag and handed them to Sir Eric Geddes, who placed it in the mail compartment of the Hengist. The ceremony was heavily promoted by the PR department of the GPO. Five news reel companies recorded the speeches and ceremony, which was exhibited in both the UK and Australia. The Paramount Film Company charted a plane to take aerial pictures of the Hengist in flight. Arrangements were made for the BBC to broadcast the speeches to Britain and the Empire. Copies of the speeches and information were prepared and distributed to the 
national press. ${ }^{[13]}$ The speeches and ceremony appeared in the daily national newspapers the following Monday (The Times, 1934a; Daily Mail, 1934; Daily Telegraph, 1934; Sunday Express, 1934). The minutes of the publicity committee of the GPO recorded that, "The event received over 2,000 column inches of press editorial, 15 leading articles, and many photographs in the National, Provincial and Aviation Press.”[14]

Such staged PR events assisted the GPO brand not only in terms of prestige and brand awareness, but also in the content of the speeches that accompanied them. These speeches revolved around themes of imperial co-operation and a strengthening of the imperial family through increased communication. On the inauguration of the above airmail to Australia, for example, The Times wrote that, "Lord Londonderry described the air route to Australia as a really imperial organisation, shared between Indian, the Dominions and Colonies and the mother country. It was a true sign of the imperial spirit of co-operation which was an indispensable factor in the efficiency of our air communication” (1934a). Mr S.M. Bruce, the Australian high commissioner stated in a message read out at the ceremony that, “ ... every step that resulted in accelerating communication and travel between the Dominions and the mother country served to make closer and more real the union between the component parts of the Empire, for a better knowledge and understanding of each other's needs and aspirations that inevitably flow from a speedy exchange of views and visits" (Daily Telegraph, 1934).

The GPO followed a similar PR strategy of event management and editorial for the launch of international radio telephony in the 1930s. Whilst international calls were prohibitively expensive, they nevertheless provided prestige value for GPO's corporate brand. Both the ceremonies for the first telephone call to Australia in 1931 by the lord mayor of London to the lord mayor of Sydney, and the first telephone call to India in 1933 by the secretary of state for India, Sir Samuel Hoare, to Sir Frederick Sythes, the governor of Bombay (Mumbai), were filmed on Pathé Newsreel (British Pathé, 1931, 1933a). In relation to the first call to India, the Daily Mail commented that the inauguration of the international telephone service held out the real possibility of economic union within the Empire, echoing Sir Samuel Hoare's comments that the telephone helped counter the two key enemies of the Empire, time and distance (1933a; The Times, 1933a). The theme of imperial unity via telecommunications was demonstrated in February, 1935 when a 'radio-telephonic' luncheon was held between South Africa and London. Present were British and South African ministers, members of the Overseas League (a prestigious pro-imperial organisation), and members of the 'Fifth Imperial Press Conference', which was being held in South Africa at the Cape. ${ }^{[15]}$ On the British side, the event was instigated by the GPO, who approached the Overseas League and convinced them to hold a luncheon at the Hyde Park Hotel where the main speaker was the postmaster general. ${ }^{[16]}$ The carefully choreographed speeches, which were broadcasted by the BBC and sent to the press by the GPO, revolved around themes of imperial unity and telecommunication. A message sent by King George V stated that he shared the hope expressed in the conference speeches, “... that the great discoveries which have been made in radio-telephony will still further strengthen that friendly co-operation and 
understanding between the nations of the British Empire” (The Times, 1935). Here was a clear antidote to the all-pervading recriminations of imperial decline and disunity.

King George V's comments touched on one other myth that the GPO told in the 1930s, that of strength and progress through scientific research and the application of technology. In the interwar period the GPO was one of the most technologically advanced corporations in Britain. During the period it developed international radio-telephony, automatic telephone exchanges, keyboard telegraphy and improvements in long distance telephone calls. The association between technology, the GPO and service to the nation was interwoven into its corporate brand and actively communicated (Anthony, 2011, p. 10; Campbell-Smith, 2011, p. 277). This is seen, for example, in the 1933 GPO film documentary, The coming of the dial (Legg, 1933). The film was a scientific documentary that showed the public the research and technical work of the GPO. It focused on the development and building of an automatic telephone exchange in the City of London, which replaced the older manual system. The film was highly modernist in production and style. It was replete with images of technology - of laboratories, circuits, wires, electromagnetic relays, control boards, mechanisms and automation. A key theme of the film was the social progress that this technology rendered, and through it the service that the GPO furnished to society. The film began with images of futuristic apparatus swirling kaleidoscopically in front of the camera. The narrator commenced his story, paying homage to the wonders of science and technology,

Research the creative power behind the modern world, building the future in the laboratory. The industrial chemist determining a carbon percentage for a safety steel. The physicist analysing colour light rays for signal lenses. The plant breeder pollinating selected grasses for mountain pastures. These men are applying the laws of science to everyday problems. And research into the behaviour of electromagnets has revolutionised the telephone system and introduced the dial (Legg, 1933).

The film ended with the completion of the modernistic telephone exchange, images of Blackfriars Bridge and the City of London, and the lines, 'Once more the laws of science have been applied to an everyday problem [communication] and this dial system is a vital contribution to efficiency and speed’' (Legg, 2013).

As in its development of international radio-telephony, the GPO through its editorial portrayed itself in the press and cinema as a techno-scientific organisation whose work improved people's everyday lives (Boon, 2011). Augmenting this was the message that the GPO's work in advanced communication made Britain into a stronger country on the global stage. The opening of the new GPO research laboratory at Dollis Hill in 1933 by the then prime minister Ramsey McDonald received wide coverage in the newspapers and on newsreels (The Times, 1933b; The Times, 1933c; Daily Mail, 1933c; British Pathé, 1933b). Over six hundred guests attended the opening ceremony and a special brochure was prepared for the event. ${ }^{[17]}$ In his speech McDonald praised the research work of the GPO and British scientists, stating that, 'London was the most conspicuous of all capitals in the progress and the application of electric science’ (The Times, 1933c). The caption for the Pathé Newsreel 
report read, 'New wonder house of experiment and invention' (British Pathé, 1933b). In the 1930s Pathé Newsreel made numerous news productions on the technical work of the GPO, covering topics such as its new mobile telephone office, its testing facilities at Dollis Hill and its international telephone exchange. In 1932 it produced a news report on the GPO radio transmitting station at Rugby, entitled 'The World's Greatest Radio Station' (British Pathé, 1932). The newsreel celebrated the technological wonders of the radio station, which at the time was the telecommunication hub for the British Empire. "No place is inaccessible to GBR", the film informed its audience, whilst it showed a transmitter sending out in Morse code across the globe the message, "The Post Office Rugby Station is the most powerful in the world" (1932). Such messages of strength and progress through technology did much to augment the iconic value of the GPO brand.

\section{Discussion}

In the 1930s the GPO developed a unique form of marketing in an attempt to revive its reputation and flagging commercial fortunes. This was based on developing an iconic corporate brand whose equity appealed to social and cultural values that revolved around notions of nation, community, identity and modernity. It did this by creating a public relations department and a unique form of corporate communications that manufactured myths of national character, imperial unity and technological progress in an attempt to assuage collective fears of social confliction, economic decline and national weakness. This is not to argue that the GPO was successful in resolving these anxieties. Such conclusions are beyond the historical research and reach of this article. Yet what is central in this historical case study is the singularity of this branding. This strategy was highly successful. In the 1930s the GPO rapidly increased its sale of telephones. In November 1933 Britain raised its position to ninth in the world in terms of telephone density and became first in Europe. ${ }^{[18]} \mathrm{By}$ the late 1930s the GPO was adding 200,000 new telephone subscribers a year. ${ }^{[19]}$ Indeed by May, 1937 the GPO had become so successful with telephone development that it could not keep up with demand. ${ }^{[20]}$ Promotion of the telephone was to be temporarily stopped and publicity was to focus on the GPO's efforts to increase supply. Similar success also took place in other services of the GPO such as airmail, the post office savings bank and telegrams. ${ }^{[21]}$ Airmail traffic, for example, increased from 10.8 million tons in 1935-6 to 91.2 million tons in 1938-9 (Campbell-Smith, 2011, p. 320). In addition, the reputation of the GPO rapidly improved. The parliamentary estimates debate in the House of Commons in June, 1934 commended the Post Office on improving its public image. The Postmaster General was praised for increasing its efficiency and sense of corporate pride (Grant, 1994, p. 82). The Times joined in with this chorus of approval. In December, 1934 it stated, "During the last two years things have been as rapidly changed in the Post Office as they have been in any business house in the Kingdom, and changed with as clear an eye to progress and efficiency” (Business-Like Government, 1934). Praise for the Post Office, according to the article, was now widespread.

This article has adapted Douglas Holt's work on iconic branding rather than replicated it. In How Brands Become Icons, Holt is concerned with the ability of iconic brands to solve 
cognitive tensions within individuals that revolve around identity, particularly masculinity (2004). This article has taken a different route, focusing on the capacity of iconic brands to deal with national and social anxieties. The issues that the GPO addressed created insecurity amongst individuals. They created fissures in the collective cultural framework of Britain, a country that prided itself on its social stability, its global and imperial heritage and its industrial and technological legacy. This provided an opportunity for the GPO, through its newly established PR department, to generate myths that calibrated its corporate brand. These were stories that originated in mainstream society as opposed to Holt's 'Populist Worlds' (2004, pp. 58-59). Furthermore this article has focused on the construction of an iconic corporate brand, rather than the multiple product brands, which How Brands Become Icons investigates, and has located its communication predominantly in public relations rather than advertising. This is in no way intended to undermine the force of Holt's account, but rather to demonstrate that his approach can be more versatile. It can examine iconic brands in relation to social as well as cognitive tensions, can focus on corporate as well as product brands, and is able to look to other communication tools beyond advertising.

The process via which organisations develop iconic corporate brands is demonstrated in Figure 4 in the lower right hand corner. The other three parts come from Holt's existing model, 'The Structure of a Myth Market' (Holt, 2004, p. 58). Organisations absorb myths from the mainstream world and reformulate these into corporate myths that become embedded in the organisation. These myths are recycled back to society, normally communicated via techniques associated with public relations. They attempt to resolve cultural contradiction in the same way as Holt's identity myths do, though deal more with macro and collective issues. Such myths provide corporations with organisation legitimacy and enhanced corporate reputation. They establish trust and credibility amongst its internal and external publics and stakeholders. They contribute to the creation of corporate identities and corporate brands, which create powerful halo effects around its products and services. They thus provide the organisation with political, institutional and market benefits. Such myths are situated in a number of loci and can address a multitude of issues, as has been demonstrated in this article. Examples include myths of technology, community and national identity, which were seen in the case of the GPO, but can include other themes such as public service, education, health and well-being, corporate responsibility and environmental protection. 
Figure 4. The Structure of a Myth Market for Iconic Product and Corporate Brands

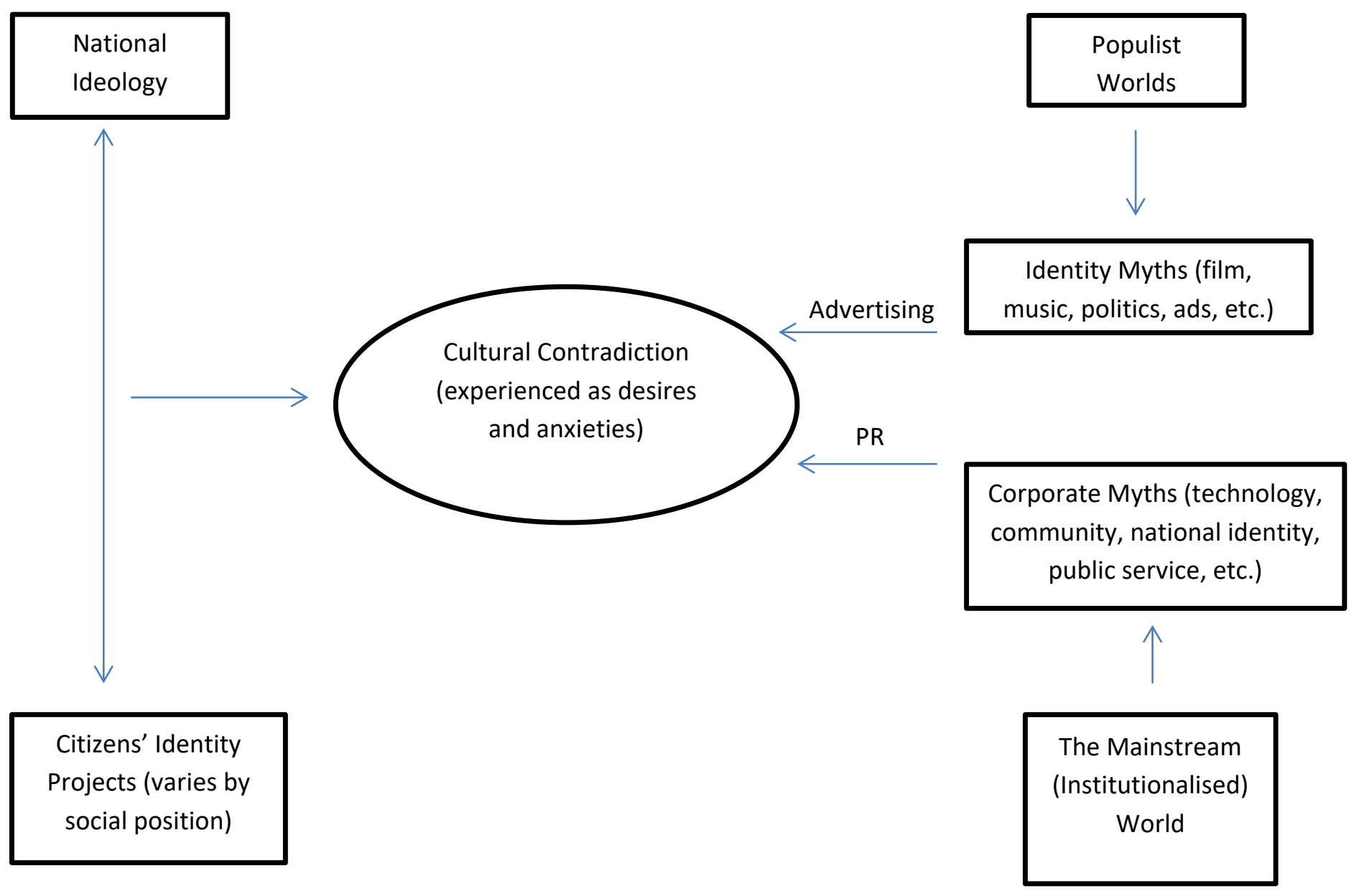

How are organisations able to absorb myths from the outside world and recycle them for their own purposes? Help in answering this question is provided by the New Institutionalism. This academic movement developed within sociology and organisational studies in the 1970s and 1980s (Powell \& Pugh, 2008; DiMaggio \& Powell, 1991). One of its central tenets is that organisations are deeply embedded in their social environments. Imbrication takes place through the development of institutions in society such as government, education, professional groups, civil associations and public opinion. These create influential patterns of behaviour and ideologies such as rationality, technical expertise, professionalism, managerialism and accountability that act as normative and cognitive structures which regulate, script and routinize social behaviour. Such structures are argued to colonise organisations (Meyer \& Rowan, 1977). Their rational, technical and bureaucratic structures are as much the outcome of social institutionalisation - the transference of institutions from society to organisations - as they are a result of the outcome of organisational efficiency. It is thus not the organisation that is institutionalised, but rather the social environment, which organisations embed themselves in (Lipartito \& Sicilia, 2004, p. 14). This is done through a 
process of institutional isomorphism whereby organisations come to copy and reflect their social environments and each other. Such a process explains why so many organisations in post-industrial society, be they businesses, schools, hospitals or government, are so similar (Meyer \& Rowan, 1977; DiMaggio \& Powell, 1983).

Paul DiMaggio and Walter W. Powell argue that institutional isomorphism is the outcome of three processes; coercive, mimetic and normative (1983). That is they are produced by political pressures and laws, the need to deal with uncertainty by organisations modelling themselves on each other, and by the production of a common system of behaviour and values, usually due to professional development and universal educational systems. What undergirds all of this is the need for organisational legitimacy. The New Institutionalism views rationalised institutional rules as essentially myths - ideological stories that have both practical and symbolic valence for society. The incorporation of these myths by organisations provides them with legitimacy. As John W. Meyer and Brian Rowan argued in their pioneering article on the New Institutionalism,

...organizations which exist in highly elaborated institutional environments and succeed in becoming isomorphic with these environments gain the legitimacy and resources needed to survive. In part, this depends on environmental processes and on the capacity of given organizational leadership to mold these processes. In part, it depends on the ability of given organizations to conform to, and become legitimated by, environmental institutions (Meyer \& Rowan, 1977, p. 352).

What is essential here is that organisations not only absorb these institutional myths, but actively demonstrate to their social and political environment, often through symbolic and ceremonial means, that such imbrication has taken place. It is through this process of absorption and articulation that organisational legitimacy occurs (Meyer \& Rowan, 1977).

The New Institutionalism provides compelling support for the model of iconic corporate branding presented in this article. The same process of incorporation, absorption and reprocessing of social myths is evident in both. So too is the outcome of organisational legitimacy and corporate reputation. When combined with Holt's theory of iconic branding and myth markets an explanation is given of the process of iconic corporate branding. During periods of uncertainty organisations incorporate myths that have been institutionalised in mainstream society, embed these within their own corporate identities and communicate them back to society in order to resolve tensions and contradictions and create corporate legitimacy in the process. Whilst the New Institutionalism has focused mainly on myths of rationalised institutional rules, there is no reason why other institutionalised social myths cannot be incorporated by organisations. Roger Friedland and Robert R. Alford have emphasised the variety of institutional myths in society at any given time (1991). They have also noted the material and symbolic advantages of these myths to organisations. In addition, the sociologist W.R. Scott has delineated three different pillars of the institutional order; the regulative, normative and cultural/cognitive (Scott, 2001). Each provides a different rationale for 
legitimacy within organisation. The normative and cultural/cognitive pillars clearly relate to the myths generated by the GPO in the interwar period.

A final question is how does this new model of iconic corporate branding fits into the existing literature on corporate identity, branding and communication reviewed above? It can be argued that there is relatively little friction between the two. Iconic corporate branding is simply a type of corporate branding and is certainly not incommensurate with existing approaches and models. From the case study it is clear that the corporate brand that the GPO developed was premised on a distinct identity, which enveloped a range of associations such as Britain, modernity, community and empire, and encapsulated distinct values such as public service, patriotism and co-operation. Elaborating on Balmer and Soenen's model (1999), this identity (the soul) was linked to both the service of telecommunications which the GPO offered and its strategy of increasing telephone penetration and imperial communication (the mind), and the development and communication of myths (the voice). In addition, the corporate identity management mix was clearly adhered to. The iconic branding strategy of the GPO was premised on a response to contradictions in its environment, communication with multiple stakeholders such as customers, the public, the media, government, and an enhancement of corporate reputation. The distinct identity that the GPO developed was a core part of its positioning in its iconic corporate branding, and the myths that the GPO derived from this to resolve contradictions in society clearly relates to corporate communication. The model of iconic corporate branding shows the integral relationship between corporate identity, corporate branding and corporate communication.

\section{Conclusion}

The development of an iconic brand by the GPO in 1930s Britain provides an important case study. It demonstrates the applicability of Holt's work on iconic brands to corporate branding. It shows that the development of iconic corporate brands requires that they are embedded in their social and cultural landscapes. In the case of corporate brands these environments do not need to exist on the fringes and can be part of mainstream society. Indeed, in the contemporary post-modern world it may well be that iconic product brands draw their sustenance from popular, alternative worlds whilst iconic corporate brands inhabit conventional society. Further research could examine the relationship between the two. Such work would demand social, cultural and potentially historical analysis and would need to be sensitive to the mode of communication of iconic product and corporate brands. It has been suggested that iconic product brands utilise advertising more, whilst iconic corporate brands use public relations. Further research could clarify this. Furthermore an historical analysis of iconic corporate branding at the GPO in the 1930s provides understanding in terms of both discourse and legacy. The GPO was one of the first organisations in Britain to develop an iconic commercial brand that projected national identity in order to deal with social issues. Its techniques and principles, developed and practiced by Tallents and Grierson, have become the basis of similar branding by other organisations, which has continued to the present. One has only to look, for example, to the opening ceremony of the 2012 London Olympics (YouTube, 2012). Its portrayal of Britain and British identity, loosely based on its history, its 
industrial legacy, its literature, its sport, the National Health Service, its popular music, its science and its peoples can be traced back to the writings and ideas of Sir Stephen Tallents and John Grierson. In the 1930s the GPO created a form of iconic branding that was adopted, via a process of institutional isomorphism, by subsequent generations. Historical analysis combined with Holt's theory of iconic branding and the New Institutionalism discloses the origins and provenance of this singular form of marketing. Further research could show its subsequent evolution. 


\section{References}

Abratt, R. and Kleyn, N. (2012), "Corporate identity, corporate branding and corporate reputations: Reconciliation and integration”, Journal of European Marketing, Vol. 46 Nos 78, pp. 1048-1063.

Aitken, I. (1990), Film and reform: John Grierson and the documentary film movement, Routledge: London.

Ankersmit, F.R. (2001). Historical Representation, Stanford University Press, Stanford, California.

Anthony, S. (2011), “The GPO film unit and 'Britishness' in the 1930s”, in Anthony, S. and Mansell, J.E. (Eds), The projection of Britain. A history of the GPO film unit, Palgrave Macmillan, Houndmills, Basingstoke.

Anthony, S. (2012), Public relations and the making of modern Britain. Stephen Tallents and the birth of a progressive media profession, Manchester, Manchester University Press.

Anthony, S., \& Mansell, J.E. (Eds.) (2011). The projection of Britain. A history of the GPO film unit, Palgrave Macmillan, Houndmills, Basingstoke.

Balmer, J.M.T. (2001), “Corporate identity, corporate branding and corporate marketing: Seeing through the fog”, European Journal of Marketing, Vol. 35 Nos 3-4, pp. 248-291.

Balmer, J.M.T. (2012), "Strategic corporate brand alignment: perspectives from identity based views of corporate brands”, European Journal of Marketing, Vol. 46 Nos 7-8, pp. 1064-1092.

Balmer, J.M.T. and Greyser, S.A. (2006), "Corporate marketing: Integrating corporate identity, corporate branding, corporate communications, corporate image and corporate reputation”, European Journal of Marketing, Vol. 40 Nos7-8, pp. 730-741.

Balmer, J.M.T. and Soenen, G.B. (1999), “The acid test of corporate identity management”, Journal of Marketing Management, Vol. 15 Nos 1-3, pp. 69-92.

Barthes, R. (2000). Mythologies. Vintage, London.

Boon, T. (2011), "Old industry, new science? The GPO Film Unit between palaeotechnology and neotechnology”, in Anthony, S. and Mansell, J.E. (Eds), The projection of Britain. A history of the GPO film unit, Palgrave Macmillan, Houndmills, Basingstoke.

British Pathé, available at: http://www.britishpathe.com/pages/newsreels. 
British Pathé. (1931), “The longest telephone call in the world”, available at: http://www.britishpathe.com/video/longest-telephone-call-in-the-

world/query/the+longest+telephone (accessed 6 October 2013).

British Pathé. (1932), “The world’s greatest radio station aka Rugby wireless station”, available at: http://www.britishpathe.com/search/query/the+worlds+greatest+radio+station (accessed 6 October 2013).

British Pathé. (1933a), "Hullo ... India aka hello India”, available at: http://www.britishpathe.com/video/hullo-india-aka-hello-india/query/aka+hello+india (accessed 6 October, 2013).

British Pathé. (1933b), “G.P.O.’s research station”, available at: http://www.britishpathe.com/search/query/gpo+research+station (accessed 6 October, 2013).

Campbell-Smith, D. (2011), Masters of the post. The authorized history of the Royal Mail, Allen Lane, London.

Carr, E.H. (1961), What Is History? Vintage, New York.

Daily Express (1933), “If Trafalgar is Fought Again”, 21 October, p. 10.

Daily Mail (1933a), “Hullo India”, 2 May, p. 2.

Daily Mail (1933b), “Air Fleet Must be Supreme”, 13 October, p. 15.

Daily Mail (1933c), “Best in the World”, 24 October, p. 11.

Daily Mail (1934), “World Air Service Joint British-US Plan? Australia Route Speed-Up”, 10 December, p. 14.

Daily Telegraph (1934), “First Air Mail to Australia”, 10 December, p. 5.

DiMaggio, P.J., \& Powell, W. (1983), “The Iron Cage Revisited: Institutional Isomorphism and Collective Rationality in Organizational Fields”, American Sociological Review, Vol. 48, April, pp. 147-160.

DiMaggio, P.J., \& Powell, W. (1991), "Introduction”, in Powell. W. (Ed), New Institutionalism in Organizational Analysis, The University of Chicago Press, Chicago.

Friedland, R., \& Alford, R.R. (1991), "Bringing Society Back In: Symbols, Practices, and Institutional Contradictions”, in Powell. W. (Ed), New Institutionalism in Organizational Analysis, The University of Chicago Press, Chicago. 
Grant, M. (1994), Propaganda and the Role of the State in Inter-War Britain, Clarendon Press, Oxford.

Grierson, J. (Director) (1934). Granton trawler [Motion Picture]. Britain: GPO Film Unit.

Hatch, M.H. and Schultz, M. (2008), Taking Brand Initiative. How Companies Can Align Strategy, Culture and Identity Through Corporate Branding, Jossey-Bass, San Francisco, CA.

Heller, M. (2010), “Corporate brand building: Shell-Mex Ltd in the interwar period”, in Lopes, T.D.S. and Duguid, P. (Eds), Trademarks, brands and competitiveness, Routledge, London.

Holt, D. (2002), "Why do brands cause trouble? A dialectical theory of consumer culture and branding”, Journal of Consumer Research, Vol. 29, June, pp. 70-90.

Holt, D. (2004), How brands become icons. The principles of cultural branding, Harvard Business School Press, Boston, MA.

Holt. D. (2006), “Jack Daniel's America: Iconic brands as ideological parasites and proselytizers”, Journal of Consumer Culture, Vol. 6 No. 3, pp. 355-377.

Humphreys, A. (2010), "Semiotic Structure and the Legitimisation of Consumption Practices: The Case of Casino Gambling”, Journal of Consumer Research, Vol. 37, October, pp. 490510.

Karababa, E., \& Ger, G. (2011), "Early Modern Ottoman Coffeehouse Culture and the Formation of the Consumer Subject”, Journal of Consumer Research, Vol. 37, February, pp. 737-760.

Kennedy. P. (1989), The rise and fall of the great powers: Economic change and military conflict from 1500 to 2000, Fontana Press, London.

Legg, S. (Director) (1933), The coming of the dial [Motion Picture], GPO Film Unit, Britain.

LeMahieu, D.L. (1988), A culture for democracy. Mass communication and the cultivated mind in Britain between the wars, Oxford University Press, Oxford.

Levi-Strauss, C. (1995), Myth and Meaning, Schocken Books, New York.

Lipartito, K., \& Sicilia, D.B. (2004), Constructing corporate America: History, politics, culture, Oxford University Press, Oxford. 
Mandler, P. (2006), The English national character: The history of an idea from Edmund Burke to Tony Blair, Yale University Press, New Haven.

McCracken, G. (2005), Culture and Consumption II: Markets, Meaning and Brand Management, Indiana University Press, Bloomington.

McKibbin, R. (2000), Classes and cultures: England 1918-1951, Oxford University Press, Oxford.

Melawar, T.C., Gotsi, M. and Andriopoulos, C. (2012), "Shaping the research agenda for corporate branding: avenues for future research", European Journal of Marketing, Vol. 46 No. 5, pp. 600-608.

Meyer, J.W., \& Rowan, B. (1977), "Institutionalized Organizations: Formal Structure as Myth and Ceremony”, American Journal of Sociology, Vol.83 No. 2, pp. 340-363.

Powell, W.W., \& Colyvas, J.A. (2008), “New Institutionalism”, in Clegg, R. and Bailey, J.R. (Eds), International Encyclopedia of Organization Studies, Sage Publications, Los Angeles \& London.

Pugh, M. (2009), We danced all night: A social history of Britain between the wars, Vintage, London.

Schroeder, J.E., \& Salzer-Morling, M. (Eds) (2006), Brand Culture, Routledge, London.

Schwarzkopf, S. (2009), "Discovering the Consumer: Market Research, Product Innovation, and the Creation of Brand Loyalty in Britain and the United States in the Interwar Years", Journal of Macromarketing, Vol. 29 No. 8, pp. 8-20.

Scott. W.R. (2001), Institutions and Organizations, Sage, Thousand Oaks, CA.

Slotkin, R. (1985), The Fatal Environment: The Myth of the Frontier in the Age of Industrialization, 1800-1890, University of Oklahoma Press, Norman, OK.

Sotkin, R. (1998), Gunfighter Nation: The Myth of the Frontier in Twentieth Century America, University of Oklahoma Press, Norman, OK.

Smith, G., \& Speed, R. (2011), "Cultural branding and political marketing: An exploratory analysis”, Journal of Marketing Management, Vol. 27 Nos 11-12, pp. 1304-1321.

Smith, R.A. \& Lux, D.S. (1993), "Historical Method in Consumer Research; Developing Causal Explanations of Change”, Journal of Consumer Research, Vol. 19, March, pp. 595610. 
Spice, E. (Director) (1936), Calendar of the year [Motion Picture], GPO Film Unit, Britain.

Suga, Y. (2011). “GPO films and modern design”, in Anthony, S. and Mansell, J.E. (Eds), The projection of Britain. A history of the GPO film unit, Palgrave Macmillan, Houndmills, Basingstoke.

Sunday Express (1934), “The King’s Gift”, 9 December, p. 7.

Tadajewski, M. \& Brian Jones, D.G. (2014), "Historical research in marketing theory and practice: a review essay”, Journal of Marketing Management Vol. 30 Nos 11-12, pp. 12391291.

Tallents, S. (1933), The projection of England, Faber \& Faber, London.

The Times (1933a), “Telephone to India”, 2 May, p. 11.

The Times (1933b), “Post Office Research Work at Dollis Hill”, 13 October, p. 11.

The Times (1933c), “Post Office Research Dollis Hill Station Opens”, 24 October, p. 11.

The Times (1934a), “Air Mail to Australia”, 10 December, p. 11.

The Times (1934b), “Business-Like Government”, 18 December, p. 12.

The Times (1935), “Radio-Telephonic Luncheon”, 8 February, p. 11.

Van Riel, C.B.M. and Balmer, J.M.T. (1997), "Corporate identity: the concept, its measurement and management”, European Journal of Marketing, Vol. 31 Nos 5-6, pp. 340355.

YouTube. (2012). “Opening ceremony - London 2012 Olympic Games”, available at: http://www.youtube.com/watch?v=4As0e4de-rI\&noredirect=1. (accessed 8 December, 2013).

Zhao, X. \& Belk, R.W. (2008), "Politicizing Consumer Culture: Advertising’s Appropriation of Political Ideology in China’s Social Transition”, Journal of Consumer Research, Vol. 35, August, pp. 231-244.

\footnotetext{
[1] Royal Mail Archives. POST 108, 'Telephone Publicity Committee. Minutes of Meetings 1931-1933.'

${ }^{[2]}$ Royal Mail Archives. POST 108, 'Post Office Publicity Committee. Minutes of Meetings 1938, Minutes, $13^{\text {th }}$ October, 1938.'

${ }^{[3]}$ Royal Mail Archives. POST 108, 'Telephone Publicity Committee. Minutes of Meetings 1931-1933, Minutes $12^{\text {th }}$ July, 1933.'

${ }^{[4]}$ Royal Mail Archives. POST 108, 'Post Office Publicity Committee. Minutes of Meetings 1935 , Minutes $7^{\text {th }}$ March, 1935.'

${ }^{[5]}$ Royal Mail Archives. Post 108 Sub-series, 'Minutes and reports of the Post Office Publicity Committee, 19311938.'
} 
[6] Royal Mail Archives, POST 92/1502, 'The Post Office Green Papers. Number 8: Post Office Publicity'.

${ }^{[7]}$ Royal Mail Archives, POST 110/3180-83, 'Outposts of Britain'.

${ }^{[8]}$ Royal Mail Archives. POST 108, 'Telephone Publicity Committee. Minutes of Meetings 1931-1933, Film Unit: production programme and progress report, $3^{\text {rd }}$ November, 1933, Post Office Film Committee, Film Library: Progress Report, $3^{\text {rd }}$ November, 1933.'

${ }^{[9]}$ Royal Mail Archives. POST 108, 'Post Office Publicity Committee. Minutes of Meetings 1935, Film Committee Progress Report, $12^{\text {th }}$ January, 1935.'

[10] Royal Mail Archives. Post 108 Sub-series, 'Minutes and reports of the Post Office Publicity Committee, 1931-1938'.

${ }^{[11]}$ Royal Mail Archives. Post 108 Sub-series, 'Press and Broadcast Notices, 1925-2000'.

${ }^{[12]}$ For example, on June $30^{\text {th }}, 1937$, articles and photos based on press releases and editorial from the GPO appeared in The Times, The Daily Telegraph, The Daily Express and The Daily Mail in relation to the inauguration of the 'All Up' campaign in which letters could be sent by airmail to the British Empire for $1 \frac{1}{2}$ pence. In all papers, a large advertisement for the new scheme from the GPO either preceded or followed the article.

${ }^{[13]}$ Royal Mail Archives. POST 108, 'Post Office Publicity Committee. Minutes of Meetings 1935 , Minutes $12^{\text {th }}$ January, 1935.'

[14] Ibid.

[15] Royal Mail Archives, POST 108/123, 'Press Notice Lunch of The Overseas League, February 7, 1935'.

${ }^{[16]}$ Royal Mail Archives. POST 108, 'Post Office Publicity Committee. Minutes of Meetings 1935, General Publicity Progress report, $4^{\text {th }}$ March, 1935.'

${ }^{[17]}$ Royal Mail Archives. POST 108, 'Telephone Publicity Committee. Minutes of Meetings 1931-1933, General Publicity: Progress Report, $16^{\text {th }}$ November, 1933.'

${ }^{[18]}$ Royal Mail Archives. POST 108, 'Telephone Publicity Committee. Minutes of Meetings 1931-1933, Minutes $23^{\text {rd }}$ November, 1933.'

[19] Royal Mail Archives. POST 108, 'Post Office Publicity Committee. Minutes of Meetings 1938, Minutes, $19^{\text {th }}$ May, 1938.'

${ }^{[20]}$ Royal Mail Archives. POST 108, 'Post Office Publicity Committee. Minutes of Meetings 1936-1937, Minutes, 6th May, 1937.'

${ }^{[21]}$ Royal Mail Archives. POST 108, 'Post Office Publicity Committee. Minutes of Meetings 1935-1938.' 